\title{
Ozonetherapy for wound management in dogs [abstract]
}

\section{Susana Gabriela Gayon-Amaro, Eduardo Flores-Colin}

Ozein Vet Klinike

\section{ABSTRACT}

\section{(2) OPEN ACCESS}

\section{Citation \\ Gayon-Amaro SG, Flores-Colin E. Ozonetherapy for wound management in dogs [abstract]. Proceedings of The World Conference on Ozone Therapy in Medicine, Dentistry and Veterinary. Ancona (Italy). September 22nd - 23rd - 24th , 2017. J Ozone Ther. 2019;3(4):21-22. doi: 10.7203/ jo3t.3.4.2019.15425}

\section{Academic Editor}

Jose Baeza-Noci,

School of Medicine, Valencia

University, SPAIN

\section{Editor}

World Federation of Ozone Therapy, Bolgna, ITALY

\section{Received}

June 17, 2019

\section{Accepted}

December 08, 2019

Published

December 30, 2019

\section{Intellectual Property}

Susana Gabriela Gayon-Amaro.

This is an open access article distributed under the terms of the Creative Commons Attribution License (CC BY 4.0), which permits unrestricted use, distribution, and reproduction in any medium, provided the original author and source are credited.

\section{Author Information}

Email: gayonamaro@gmail.com
Purpose: To demonstrate the bactericide and regenerative capabilities of ozone through the execution of established protocols for infected wounds management.

\section{Patients and methods:}

- Ozone generator

- Medical oxygen

- Drinking water

- Nelaton lead
- Gauzes

- Polyethylene bags of different sizes

- $10 \mathrm{~mL}$ syringes

- 30G needles needles
Collect information of clinical cases of 5 patients with purulent wounds caused by bite of congener treated with ozone therapy (OP) with bagging technique (1) - injury washing with ozonized water and posterior bagged of affected area with polyethylene for 15 minutes with an ozone concentration of $56 \mathrm{mg} / \mathrm{L}$ and infiltration of wound edges with the gas in an antiinflammatory concentration of $33 \mathrm{mg} / \mathrm{L}$.

It was possible to observe short recovery processes of disinfection and regeneration of infected wounds using in only OP as wound management protocol.

Discussion: Ozone bactericide property is probably the most studied topic because it was early used in the management of infected wounds $(2,3)$. Later, with the invention of plastic materials, local treatment of septic limbs with gaseous ozone became possible. The regeneration helped with ozone has been intensively described, the acceleration of the process is related with cytokines release and the increase of tisular oxygenation [4].

Conclusion: Based on that, it is possible to conclude that ozonetherapy could be used as another therapeutic option in the management of infected wounds with bagging technique due to bactericide and regenerative properties of this gas.

\section{References:}

1. Menéndez CS, González AR, Ledea LO, Hernández RF, León FO, Díaz GM. Ozono: Aspectos básicos y aplicaciones clínicas. Primera edición. Cuba. Editorial CENIC Centro Nacional de Investigaciones Científicas; 2008.

2. De Monte A, Gori C. Major ozonated autohemotherapy in the treatment of limb ulcers not responding to conventional therapy. Int. J Ozone Ther. 2011;10 (2):85-98. 
3. Rakovsky S, Zaikov G. Application of ozone in Medicine. Chem Tech. 2009;3(3):237-248.

4. Valacchi G, Fortino V, Bocci V. The dual action of ozone on the skin. Br J Dermatol. 2005;153(6):1096-1100. 